Acta Geod. Geoph. Hung., Vol. 38(3), pp. 345-362 (2003)

\title{
EARTHQUAKE ACTIVITY AND HAZARD IN THE CARPATHIAN BASIN I
}

\author{
T Zsíros ${ }^{1}$
}

[Manuscript received January 2, 2002]

\begin{abstract}
The seismicity and seismic hazard of the Carpathian Basin are studied in this paper based on a recent comprehensive database cataloging over 20 thousands earthquakes between 456 and 1995 . The epicentre distributions of these events indicate the geographical positions of the most active tectonic processes in the region. Among them the south-eastern bend of the Carpathians (Háromszék-Vrancea zone, Romania) and the area of south-eastern Alps have the highest seismic activity. The former source area is very specific by its strong seismicity from the intermediate depth domain $(70-170 \mathrm{~km})$.

The intermediate-depth sources are deepening nearly vertically but in somewhat SW direction and the separation of the crustal earthquakes from the events connected to the lithospheric plate subsiding into the astenosphere is well observed at about $50 \mathrm{~km}$, which is the depth of the Mohorovičić discontinuity (MOHO) in this region. The lithospheric plate subsiding to the depth of $150-200 \mathrm{~km}$ is supposed to be disconnected around $50 \mathrm{~km}$. Some weakness of this slab can also be assumable based on the lower seismic activity observed between 100-120 km.
\end{abstract}

Keywords: Carpathian Basin; earthquake; earthquake catalog; epicenter; focal depth; Hungary; magnitude

\section{Introduction}

For studying of the seismic activity of an area we need to know first of all the earthquakes occurred in the past. The first scientific description of the earthquakes in the Carpathian Basin was compiled by János Grossinger, a Jesuit from Komárom (today Komarno in Slovakia), who published his work Dissertatio de Terrae Motibus Regni Hungariae in 1783. In the 19th century the most important earthquake catalogues of Hungary were compiled by Henrik Jeitteles (1860a, 1860b) a secondary school teacher of Kassa (today Kosice in Slovakia), and by Ede A Bielz (1862-1863) a natural scientist from Nagyszeben (today Sibiu in Romania). Similarly important works are the seismological compilations of some significant earthquakes of the Pannonian Basin: Jan. 14, 1810 - Mór (Kitaibel and Tomtsányi 1814), Jan. 15, 1858 - Zsolna /Zilina/ (Kornhuber 1858, Schmidt 1858, Hunfalvy 1859, Jeitteles 1859), Oct. 3, 1880 - Central-Transylvania (Koch 1881, Schuster 1881), Nov. 9, 1880 - Zágráb /Zagreb/ (Hantken 1882, Torbar 1882, Wahner 1883), Apr. 14, 1895 Ljubljana /Laibach/ (Suess 1897). The work of Kitaibel and Tomtsányi (Dissertatio de Terrae Motu in genere, ac in specie Mórensi anno 1810 die 14. Januarii orto. Budae, 1814) has a special importance, namely the authors firstly used the concept of isoseismal delineating an area having the same level of shaking. In the great

\footnotetext{
${ }^{1}$ HAS GGRI Seismological Observatory, H-1112, Budapest, Meredek u. 18, Hungary
} 
earthquake catalogues of the world (e.g. Hoff 1840-1841, Perrey 1846, Mallet 1858, Fuchs 1886) there are also some Hungarian events, but their contributions are much less comparing to the former works.

In this field Antal Réthly did a great step in the middle of the 20th century, by publishing the descriptions of the Hungarian earthquakes in chronological order between 456 and 1918. He collected the observations until the end of World War I, when Hungary was seriously truncated. His collection (A kárpátmedencék földrengései /Earthquakes of the Carpathian Basins/ (455-1918), Budapest, 1952) has still been a major source of earthquakes not only for Hungary, but also for the newer states (e.g. Romania, Slovakia) of the region. The parametric catalogue of Csomor and Kiss (1962) contains only the events occurred in Trianon Hungary (in the present territory of the country) between 1880-1956. The first digital earthquake catalogue was published by T Zsíros, P Mónus and L Tóth in 1988. The content of the last three databases is shown in Table I comparing with the most recent one (Zsíros 2000). The systematic collection of earthquake observations started in the years of $1880-1881$ by the establishment of the Seismological Committee of the Hungarian Geological Society. (After Switzerland the Hungarian Earthquake Committee was the second in Europe.) In Hungary the instrumental seismology started at the turn of the 19th and 20th centuries and by the beginning of the First World War (1914) the seismological network of the country (see Fig. 1) belonged to the most developed ones (Biszticsány and Csomor 1981, Szeidovitz 1994, Ferrari 1997). At that time however the instruments were very insensible, so they can record only the extremely large or the very near earthquakes, and the hegemony of macroseismology lasted until the '60s of the 20th century. Among the countries having changeable borders in the Carpathian Basin, Hungary has the most advanced position for the establishment of the most comprehensive database of historical earthquakes of this region, since the whole Carpathian Basin was Hungary for one thousand years and since this country occupies the center part of the Basin.

The source parameters of earthquakes have become to known from the evaluation processes of the macroseismic and/or the instrumental observations. In the earthquake catalogues the basic (source) parameters are usually the following ones: date and time of the event, co-ordinates of the epicenter, focal depth, magnitude, epicentral or maximum intensity. The reliability and the accuracy of the source parameters are naturally determined by the quality of the (literature) sources used. In the case of historical earthquakes (macroseismic data) we always relied on the primary (root) sources (Stucchi and Albini 1991) if they were available. In instrumental observations - if we have more network determinations - the most reliable and accurate parameters were intended to select based on e.g. the similarity with macroseismic results, the number of stations used, error estimations. In the following paragraphs some seismicity and seismic hazard results are presented based on the latest database (Zsíros 2000) for the Carpathian Basin.

Acta Geod. Geoph. Hung. 38, 2003 
Table I. Number of earthquakes in different catalogues

\begin{tabular}{|c|c|c|c|c|}
\hline & $\begin{array}{c}\text { Réthly (1952) } \\
\text { 455-1918 } \\
\text { Carpathian Basin }\end{array}$ & $\begin{array}{c}\text { Csomor and Kiss (1962) } \\
\text { 1880-1956 } \\
\text { Trianon Hungary }\end{array}$ & $\begin{array}{c}\text { Zsíros et al. (1988) } \\
456-1986 \\
44.5 \mathrm{~N}-49.5 \mathrm{~N} ; \\
15.5 \mathrm{E}-26.5 \mathrm{E} \\
\end{array}$ & $\begin{array}{c}\text { Zsíros }(2000) \\
456-1995 \\
44 \mathrm{~N}-50 \mathrm{~N} \\
13 \mathrm{E}-28 \mathrm{E} \\
\end{array}$ \\
\hline $455-1000$ & 3 & - & 3 & 5 \\
\hline $1001-1500$ & 21 & - & 17 & 74 \\
\hline $1501-1600$ & 70 & - & 82 & 174 \\
\hline $1601-1700$ & 78 & - & 80 & 136 \\
\hline $1701-1800$ & 245 & - & 245 & 446 \\
\hline $1801-1850$ & 288 & - & 313 & 642 \\
\hline $1851-1879$ & 370 & - & 386 & 1032 \\
\hline $1880-1900$ & 327 & 100 & 491 & 1760 \\
\hline $1901-1918$ & 595 & 233 & 1010 & 2475 \\
\hline $1919-1956$ & - & 540 & 1214 & 4251 \\
\hline $1957-1986$ & - & - & 1181 & 5680 \\
\hline $1987-1995$ & - & - & - & 3803 \\
\hline $455-1995$ & 1997 & 873 & 5022 & 20478 \\
\hline
\end{tabular}

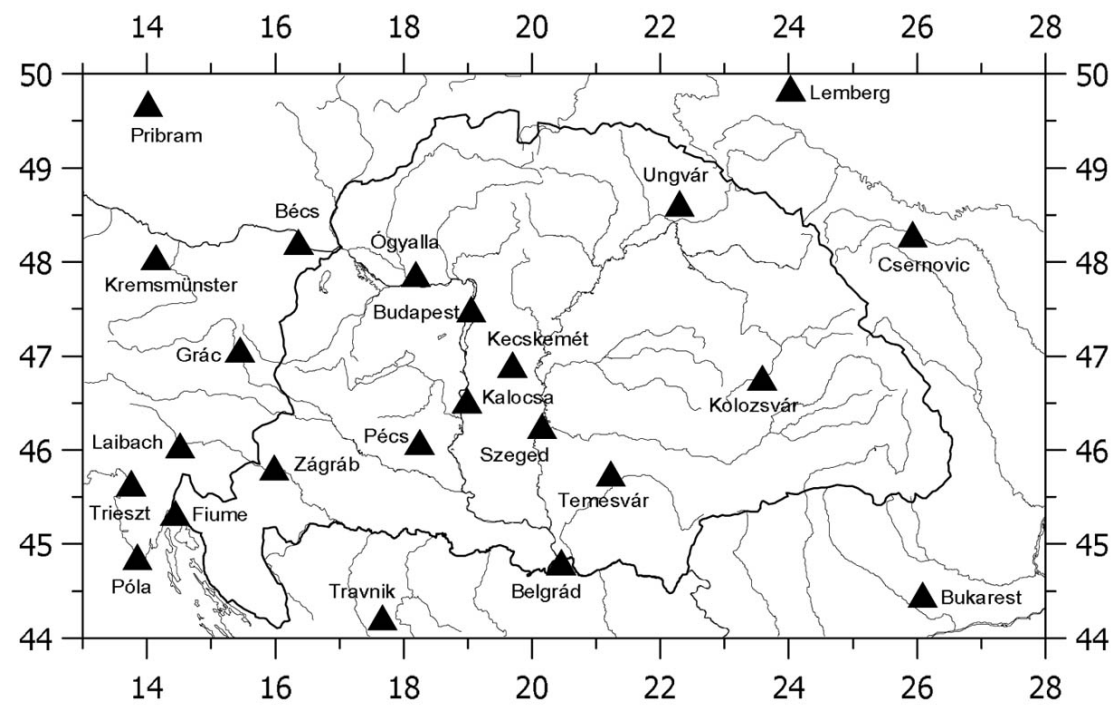

Fig. 1. Seismographic stations in the Carpathian Basin and its vicinity until 1914

\section{Epicenter}

The vertical projection of the earthquake source (hypocenter) is the epicenter on the surface, which can be determined by instrumental and macroseismic observations. In the later case the epicenter is the center of the most shaken area estimated by some method (Cecic et al. 1996). For historical events naturally the macroseismic tool is the only method. The epicenter shown in the earthquake catalogue (Zsíros 2000) is thought to be the best among the different (instrumental 
and/or macroseismic) determinations. In general the instrumental epicenter is more reliable than the macroseismic one from the '70s of the last century.

The estimation of the epicenter may be very uncertain due to poor and/or contradicted observations. Five accuracy classes of the epicenters (A: $\pm 5 \mathrm{~km}, \mathrm{~B}$ : $\pm 10 \mathrm{~km}, \mathrm{C}: \pm 20 \mathrm{~km}, \mathrm{D}: \pm 50 \mathrm{~km}, \mathrm{E}$ : it may be more than $50 \mathrm{~km}$ ) have been used in the Hungarian catalogue. Earthquakes with epicenter accuracy ' $\mathrm{E}$ ' were excluded in any studies in this paper. A peculiarity of the macroseismic method must however be noted. Namely, if there is only one single location with observation, the position of this location is chosen as the epicenter of the event. Such a case is not rear among historical earthquakes. Nevertheless, it is reasonable to assume that the records of the greatest distractions have a higher probability to survive against to the weak effects in the case of strong earthquakes. On the other hand, when the event is very weak the observation can only be possible near to the epicenter. (The above statements are valid for the vast majority of earthquakes originating from the crust with a focal depth not more than 60-70 km. The stronger intermediate-depth earthquakes at the southeast bend of the Carpathians (see paragraph 3 ) however can produce weak shaking in a larger area of the epicenter.) The positions of the most recent earthquakes determined by the Hungarian micro-seismic monitoring network (Tóth et al. 1996, 1997, 1998, 1999) seem to be connected to the known macroseismic epicenters in the region.

In general the older the event naturally the poorer the information available and Figs 2-7 demonstrate the changes in seismicity pattern during the past centuries. Until 1500 there is very few earthquake data. While there is no notable difference between the seismicity of the 16 th and the 17 th century, we have already more data from the 18th century. The epicenters of the 19th century indicate most of the seismic sources known today in the region, but the northern part of the Balkan (Bosnia, Serbia) is nearly free of earthquakes certainly due to the inadequate collection of the observations. The sources of earthquakes occurred between 4561995 in Fig. 8 - in spite of the fact that they are rather scattered in some area nevertheless outline the geographical positions of the strong tectonic movements in the Carpathian Basin.

Though the comparisons of the seismicity and the maps or models of other geosciences are out of the scope of this study it is worth to note some peculiarity of this source pattern.

- The two most active regions:

Southeastern part of the Alps connecting to the Dinarides (southern Austria, northern Italy, Slovenia, western Croatia).

Southeastern band of the Carpathians (Háromszék-Vrancea region) with the source zone of crustal events in its western neighbourhood (Barcaság region).

- There is a strong seismic source line starting from the valley of the river Mur (Mura) in Austria and continuing through the Little-Carpathians (KisKárpátok) in Slovakia. To this important source zone another very active line is connected along the rivers of Enns and Liesenbach in Austria. 


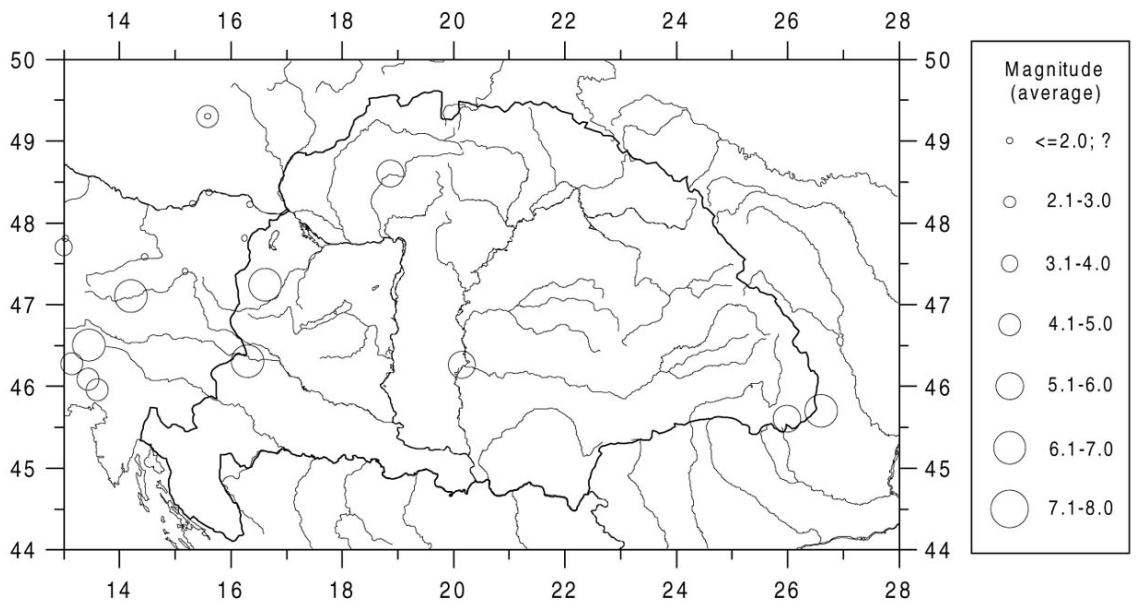

Fig. 2. Earthquake epicenters in the Carpathian Basin (456-1500) (Epicenters having more than $50 \mathrm{~km}$ deviations are not plotted)

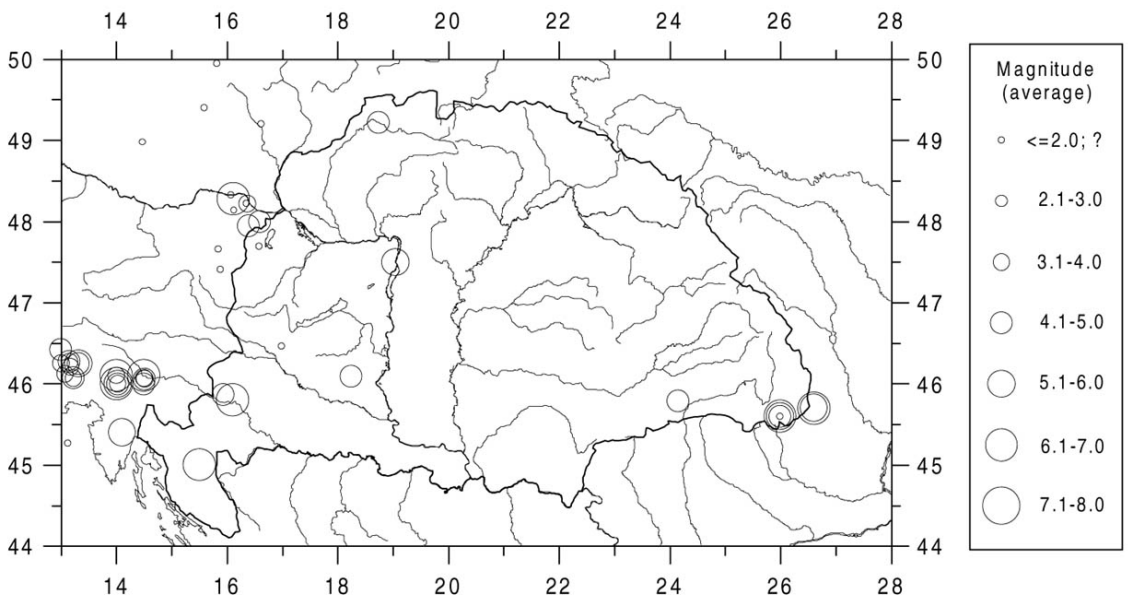

Fig. 3. Earthquake epicenters in the Carpathian Basin (1501-1600) (Epicenters having more than $50 \mathrm{~km}$ deviations are not plotted)

- The seismicity of the Sub-Carpathian (Kárpátalja) region is also apparent where the epicenters around the feet of Avas, Gutin, Köhát and Lápos mountains indicate a very active tectonic process.

- The massive platforms and shields (Bohemia, Ukraine, Oltenia) are also not without earthquakes but naturally the level of seismicity is very low. Furthermore some parts of the Pannonian Basin (e.g. northern part of the Little Hungarian Plain (Kisalföld) above the river Danube, area east of the river Tisza (Tiszántúl), northern Bácska) show smaller seismic activity than e.g. the territory of Bohemia. 


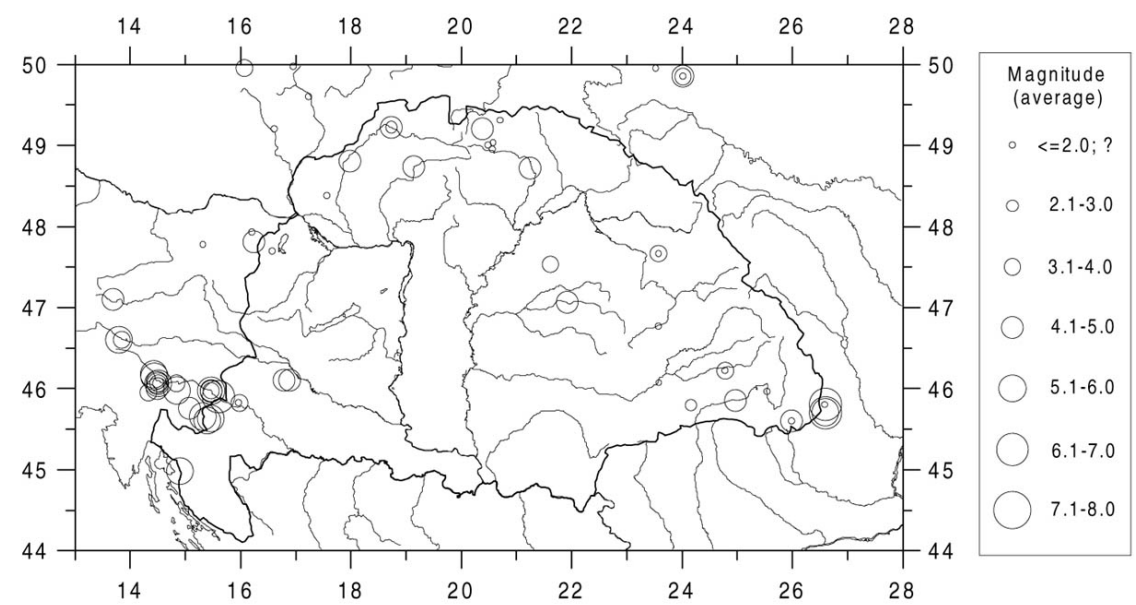

Fig. 4. Earthquake epicenters in the Carpathian Basin (1601-1700) (Epicenters having more than $50 \mathrm{~km}$ deviations are not plotted)

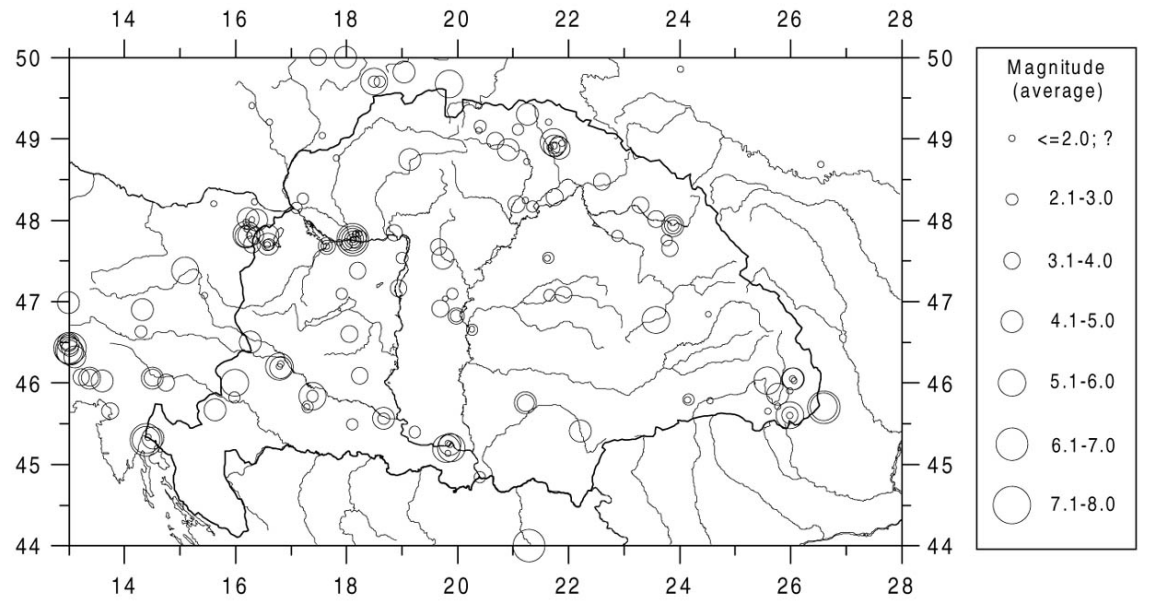

Fig. 5. Earthquake epicenters in the Carpathian Basin (1701-1800) (Epicenters having more than $50 \mathrm{~km}$ deviations are not plotted)

\section{Focal depth}

Among the total 20478 earthquakes of the database only 3751 earthquakes about $18 \%$ of the events - have focal depth values. They are either the results of network determinations or macroseismic estimations based on isoseismal maps. The later figure however is very small, only about $4 \%$ of the focal depth data. The estimation of focal depth is the most difficult one comparing to the determination of the other source parameters of earthquakes. In network determination the velocity model used is usually not precise enough and the number of input observations is often very small. The instrumental depth values of the catalogue come from database of different seismological centers. Since most of the earthquakes are not felt, the 


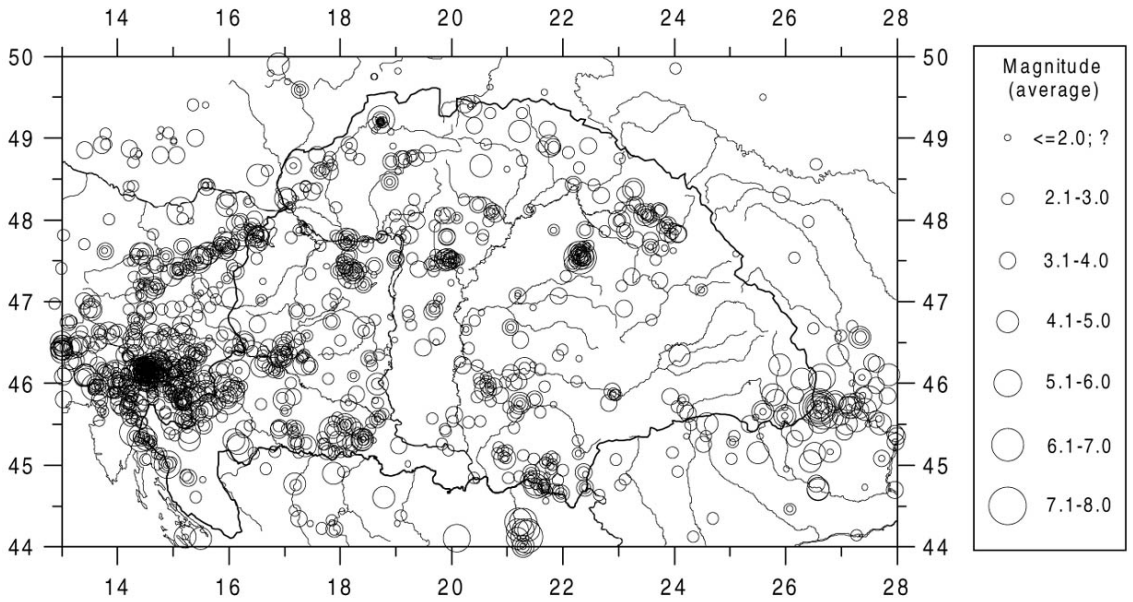

Fig. 6. Earthquake epicenters in the Carpathian Basin (1801-1900) (Epicenters having more than $50 \mathrm{~km}$ deviations are not plotted)

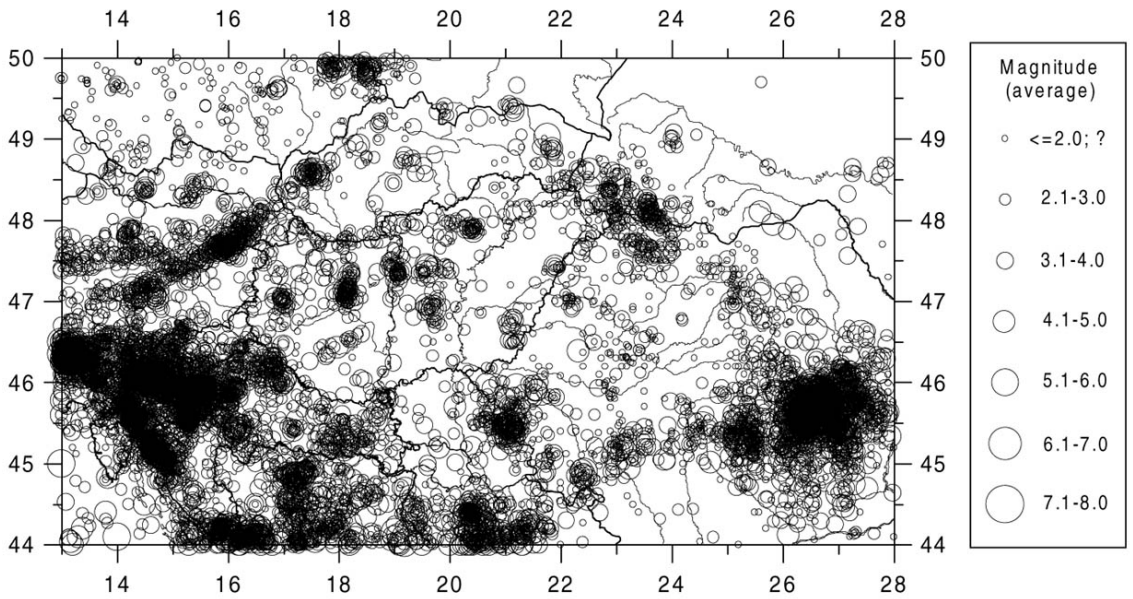

Fig. 7. Earthquake epicenters in the Carpathian Basin (1901-1995) (Epicenters having more than $50 \mathrm{~km}$ deviations are not plotted)

macroseismic depth estimation is usually not possible. For earthquakes having an isoseismal map with three isoseismals at least (in order to calculate deviations), the macroseismic focal depth was estimated in uniform way (Zsíros 1996) using the Kövesligethy formula (1906) as the intensity attenuation model.

$$
I_{0}-I_{k}=3 \cdot \log \left(D_{k} / h\right)+3 \cdot \alpha \cdot \log (e) \cdot\left(D_{k}-h\right),
$$

where:

$I_{0} \quad$ - epicentral intensity

$I_{k} \quad-\quad$ intensity value at hypocentral distance $D_{k}$

$D_{k}^{2}=R_{k}^{2}+h^{2}$

$R_{k} \quad-\quad$ adius value of isoseismal $k(\mathrm{~km})$ 


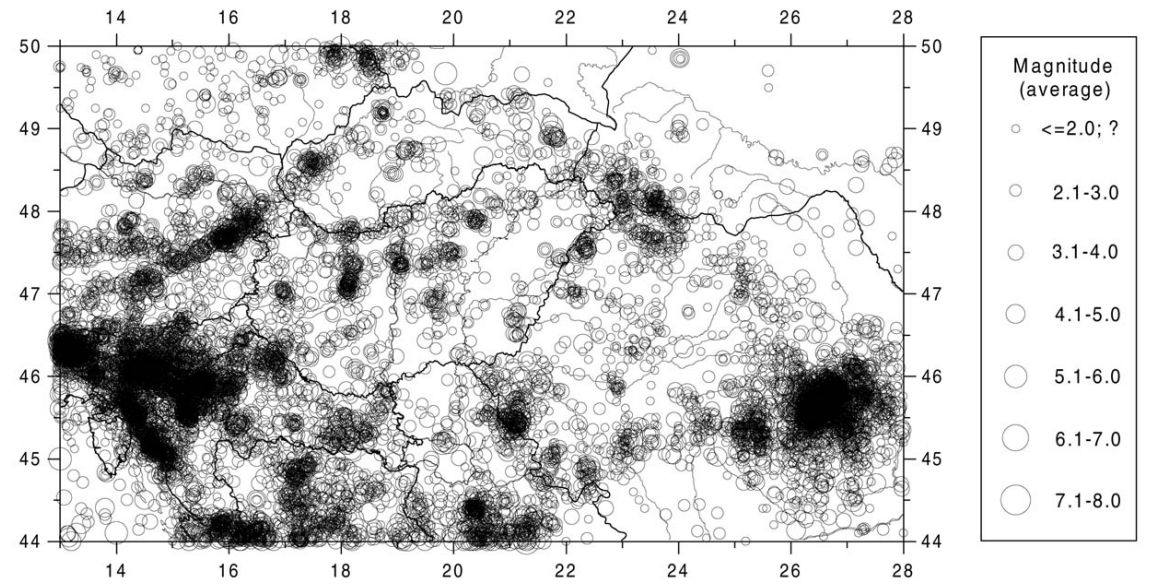

Fig. 8. Earthquake epicenters in the Carpathian Basin (456-1995) (Epicenters having more than $50 \mathrm{~km}$ deviations are not plotted)

$$
\begin{array}{ll}
h & - \text { focal depth }(\mathrm{km}) \\
\alpha & - \text { coefficient of absorption }\left(\mathrm{km}^{-1}\right) \\
\log (e) & \cong 0.4343 .
\end{array}
$$

Based on the above Eq. (1) the focal depths of 147 earthquakes have been determined, altogether.

In network determinations of source parameters of earthquakes the focal depth has often been fixed in order to obtain a stable result for epicenter co-ordinates, consequently these depth values were intended to exclude from the catalogue. The depth values having more than $100 \%$ standard deviations were also removed from the database. The values of focal depths vary between 1 and $291 \mathrm{~km}$ in the catalogue and the frequency of the individual depth values shows considerable difference.

Shallow depth $(1-65 \mathrm{~km})$ events occur in the whole territory of the Carpathian Basin, however the sources of the earthquakes with intermediate depth (66-300 $\mathrm{km}$ ) have been concentrated at the southeast bend of the Carpathians (HáromszékVrancea region). The distributions of the shallow and the intermediate earthquakes in space are shown in Fig. 9 and in Fig. 10, respectively.

Studying the histogram of focal depths of earthquakes (Fig. 11) occurring in the Carpathian Basin without the Háromszék-Vrancea region it can be concluded that $7 \mathrm{~km}$ is the most frequent depth value and $65 \%$ of the whole 1804 events are originated from the $5-15 \mathrm{~km}$ depth domain. The average depth is $12.6 \mathrm{~km}$.

Figure 12 shows the histogram of the focal depths of the Háromszék-Vrancea region between 1 and $300 \mathrm{~km}$. The total 1919 events consist of 555 shallow depth (1$65 \mathrm{~km})$ earthquakes $(29 \%)$ and 1364 intermediate depth $(66-300 \mathrm{~km})$ earthquakes (71\%). The average depth is $95.2 \mathrm{~km}$. The striking high frequencies at 100, 120, 130,140 and $150 \mathrm{~km}$ are probably due to the fact that some of the depth values are not calculated but fixed during the estimation process of source parameters. Roughly three groups can be outlined in Fig. 12 with the depth centers of $\sim 15 \mathrm{~km}$, $\sim 80 \mathrm{~km}$ and $\sim 130 \mathrm{~km}$, respectively. 


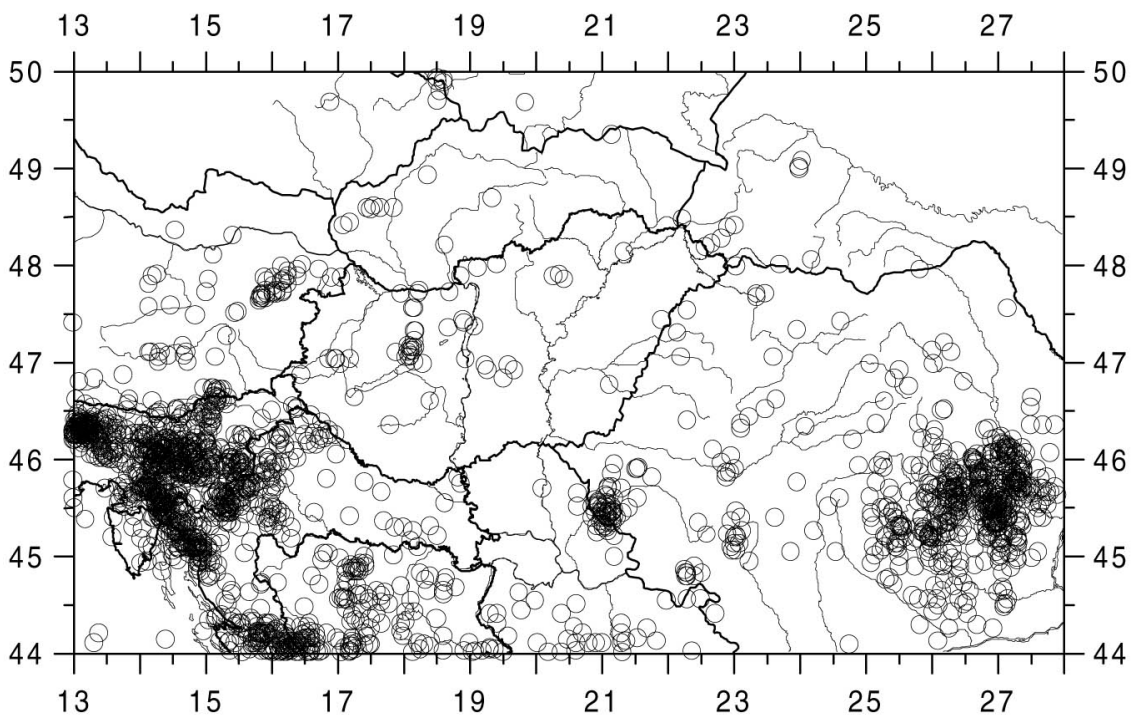

Fig. 9. The spatial distribution of earthquakes with shallow focal depth $(1-65 \mathrm{~km})$. Number of earthquakes used: 2359

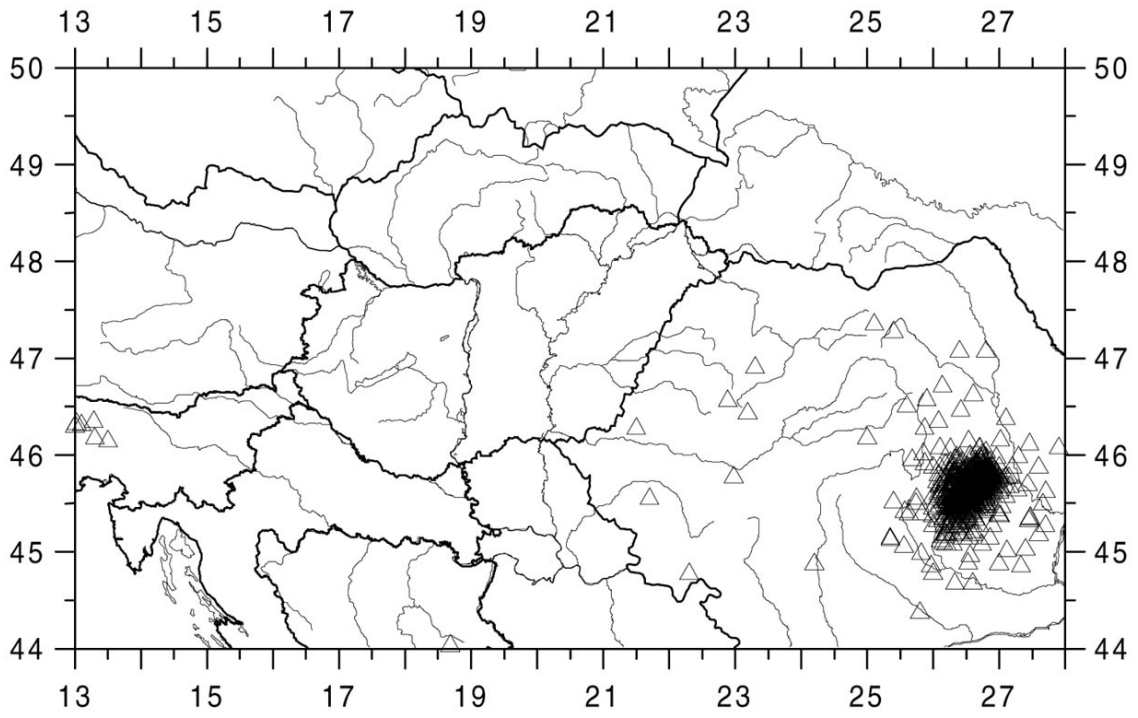

Fig. 10. The spatial distribution of earthquakes with intermediate focal depth $(66-300 \mathrm{~km})$. Number of earthquakes used: 1392

The intermediate depth sources of the Háromszék-Vrancea region are deepening nearly vertically but in somewhat SW direction (Fig. 13). The most dominant part is between 70 and $170 \mathrm{~km}$ and below $200 \mathrm{~km}$ the events are rear. In Fig. 13 the separation of the crustal earthquakes and the events connected to the lithospheric plate subsiding into the asthenosphere is well observed at about $50 \mathrm{~km}$, which is the 


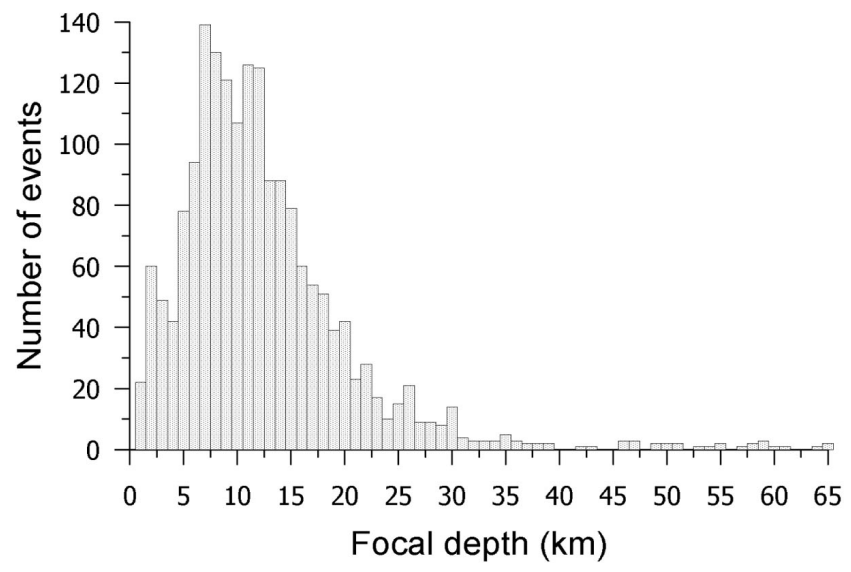

Fig. 11. Distribution of focal depths between 1 and $65 \mathrm{~km}$ in the Carpathian Basin (44-50 N; 13-28 E). Earthquakes of the Háromszék-Vrancea region (44.5-46.5 N; 25.5-28 E) are excluded. Number of events used: 1804

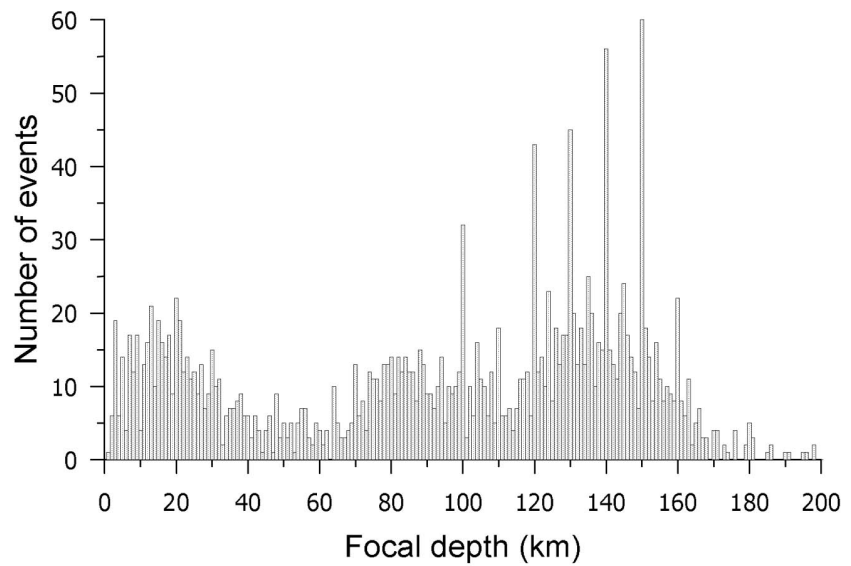

Fig. 12. Distribution of focal depths between 1-200 km in the Háromszék-Vrancea region (44.5$46.5 \mathrm{~N} ; 25.5-28 \mathrm{E})$. Number of events used: 1908

depth of the Mohorovičić discontinuity (MOHO) in this region (Lenkey 1999). The lithospheric plate deepening to the depth of 150-200 km (Horváth 1993, Lenkey 1999 ) is supposed to be disconnected around $50 \mathrm{~km}$ (Oncescu et al. 1984, Spakman 1990). Some weakness of this lithospheric plate can also be assumable based on the lower seismic activity observed between 100-120 km depth (see Figs 12 and 13). 

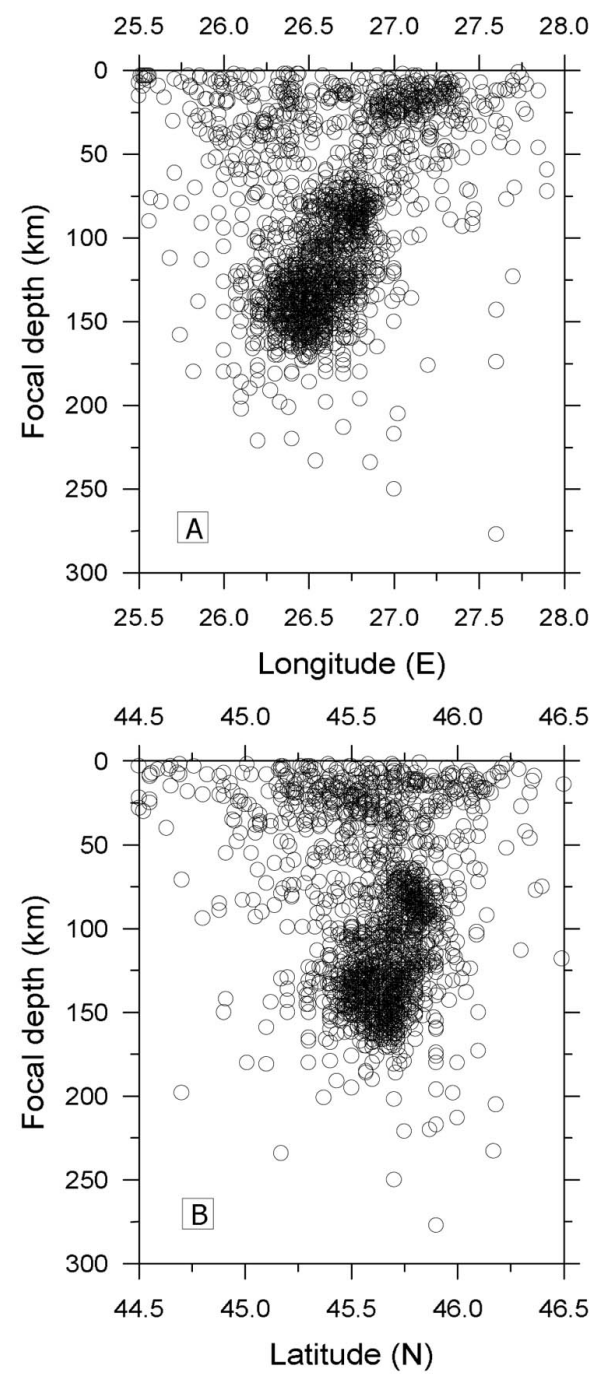

Fig. 13. Distribution of focal depths along the longitude East (A) and the latitude North (B), respectively in Háromszék-Vrancea region (44.5-46.5 N; 25.5-26.5 E). Number of events used: 1919

\section{Magnitude}

The magnitude value was introduced to provide an instrumental measure of the size of earthquakes based on the records of seismic waves by a convention (Willmore 1979). Since there are different types of seismic waves, different magnitude scales have been used. Unfortunately there is some inconsistency between the different scales and the deviations of magnitudes are often considerable ones even measured on the same scale. In the database used the most frequent types of magnitudes are the followings: MS - surface wave magnitude, MB — body wave magnitude, ML 
- local (Richter) magnitude, MD - duration magnitude. Among them the last two types of magnitudes are the most frequent ones due to their relatively easier determinations.

The regression analysis of the different types of magnitudes has the following results:

- The relation of $M_{S}$ and $M_{B}$ magnitudes:

$$
M_{S}=0.97( \pm 0.05) M_{B}+0.04( \pm 0.24)
$$

Number of earthquakes used: 127. Magnitude intervals: $M_{S}=2.5-7.0$; $M_{B}=2.1-6.4$.

— The relation of $M_{S}$ and $M_{L}$ magnitudes:

$$
M_{S}=0.86( \pm 0.06) M_{L}+0.57( \pm 0.27)
$$

Number of earthquakes used: 97. Magnitude intervals: $M_{S}=2.0-7.0$; $M_{L}=2.0-6.6$.

- The relation of $M_{S}$ and $M_{D}$ magnitudes:

$$
M_{S}=1.21( \pm 0.11) M_{D}-1.23( \pm 0.52)
$$

Number of earthquakes used: 27. Magnitude intervals: $M_{S}=2.3-6.9$; $M_{D}=2.8-6.5$.

- The relation of $M_{B}$ and $M_{L}$ magnitudes:

$$
M_{B}=0.59( \pm 0.05) M_{L}+1.75( \pm 0.22)
$$

Number of earthquakes used: 259. Magnitude intervals: $M_{B}=2.6-6.4$; $M_{L}=2.1-6.6$.

- The relation of $M_{B}$ and $M_{D}$ magnitudes:

$$
M_{B}=0.90( \pm 0.08) M_{D}+0.20( \pm 0.32)
$$

Number of earthquakes used: 160 . Magnitude intervals: $M_{B}=2.6-6.3$; $M_{D}=3.2-6.5$.

— The relation of $M_{L}$ and $M_{D}$ magnitudes:

$$
M_{L}=1.14( \pm 0.02) M_{D}-0.69( \pm 0.06)
$$

Number of earthquakes used: 894. Magnitude intervals: $M_{L}=0.8-5.5$; $M_{D}=1.4-5.6$. 

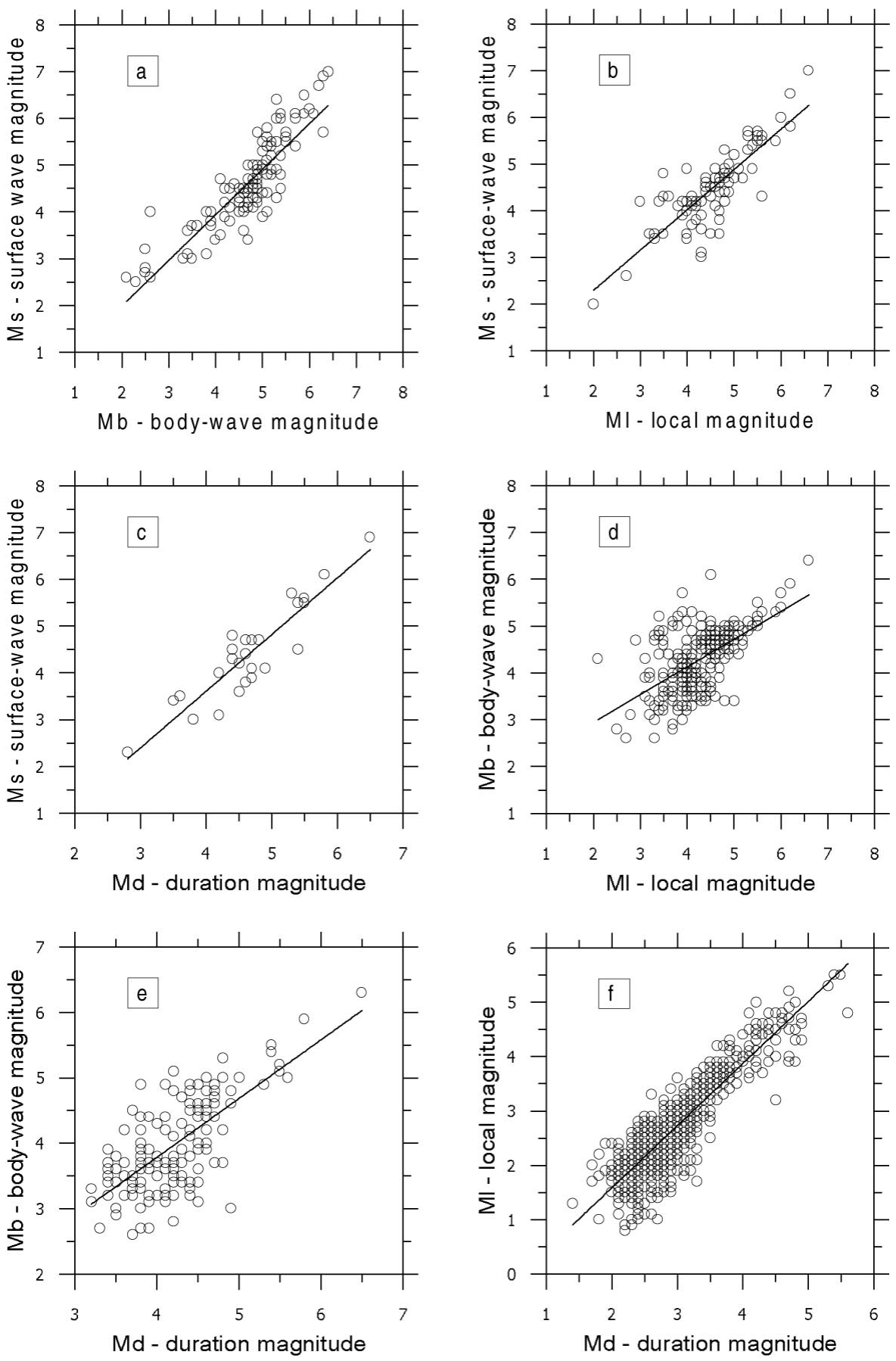

Fig. 14. Relations between different types of magnitudes based on earthquakes of the Carpathian Basin (44-50 N; 13-28 E) 
The fit of the regression curves is shown in Fig. 14.

Relationship between the average magnitude $(M)$ and the epicentral intensity $\left(I_{0}\right)$.

Magnitudes of earthquakes have frequently to be estimated from macroseismic data due to the lack of instrumental data. It seems to be reasonably supposed that the magnitude value depends first of all on the epicentral intensity and the focal depth of the earthquake. The constant parameters of the empirical formula (8) were estimated by the least-square method.

$$
M=a \cdot I_{0}+b \cdot \log (h)+c
$$

where:

$M \quad$ - average instrumental magnitude

$I_{0} \quad-$ epicentral intensity

$h \quad-$ focal depth $(\mathrm{km})$

$a, b, c-$ constant parameters.

The regression analysis was carried out for two territories:

- The whole Carpathian Basin (44-50 N; 13-28 E) but without the HáromszékVrancea region $(44.5-46.5 \mathrm{~N} ; 25.5-28.0 \mathrm{E})$ which contains the intermediatedepth events.

— The Háromszék-Vrancea region (44.5-46.5 N; 25.5-28.0 E).

The resulted relationships are as follows:

- Carpathian Basin:

$$
M=0.68( \pm 0.02) I_{0}+0.96( \pm 0.07) \log (h)-0.91( \pm 0.10) .
$$

Number of earthquakes used: 514. Depth interval: 1-65 km. Range of the epicentral intensities: from III to IX-X. Magnitude interval: 0.6-6.2.

Using $12.6 \mathrm{~km}$ as the average focal depth determined from 1804 earthquakes (see paragraph 3) in Eq. (9) the relation between $M$ and $I_{0}$ is the following:

$$
M=0.68 \cdot I_{0}+0.146 .
$$

- Háromszék-Vrancea region:

$$
M=0.52( \pm 0.02) I_{0}+0.55( \pm 0.11) \log (h)+1.18( \pm 0.20) .
$$

Number of earthquakes used: 130. Depth interval: 1-200. Range of epicentral the intensities: from II to IX. Magnitude interval: 2.4-7.3.

Using $95.2 \mathrm{~km}$ as the average focal depth determined from 1919 earthquakes (see paragraph 3) in Eq. (11) the relation between $M$ and $I_{0}$ can be written as:

$$
M=0.52 \cdot I_{0}+2.27 .
$$

The fitting of Eqs (10) and (12) to the observations is shown in Fig. 15. Some earlier determined magnitude-intensity relationships for the regions studied: 


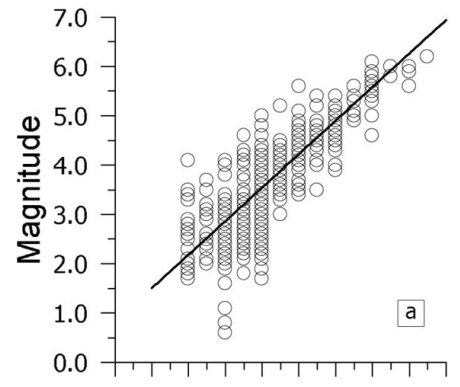

$\begin{array}{lllllllllll}1 & 2 & 3 & 4 & 5 & 6 & 7 & 8 & 9 & 10\end{array}$ Epicentral intensity

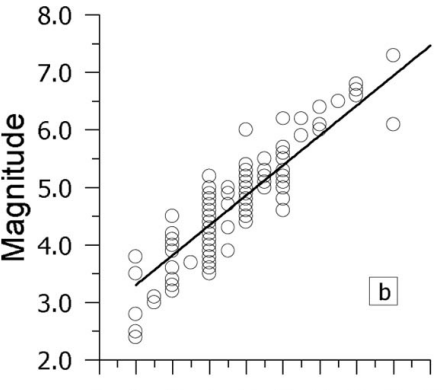

$\begin{array}{lllllllllll}1 & 2 & 3 & 4 & 5 & 6 & 7 & 8 & 9 & 10\end{array}$ Epicentral intensity

Fig. 15. Relation between the (average) magnitude and the epicentral intensity: a) Carpathian Basin (44-50 N; 13-28 E) (without Háromszék-Vrancea region (44.5-46.5 N; 25.5-28.0 E)). The regression curve calculated with a mean depth of $12.6 \mathrm{~km}$. Number of data used: 514 . b) HáromszékVrancea region (44.5-46.5 N; 25.5-28.0 E). The regression curve calculated with a mean depth of $95.2 \mathrm{~km}$. Number of data used: 130

- Present territory of Hungary:

$$
M=0.6 \cdot I_{0}+0.3 \quad \text { (Csomor and Kiss 1959). }
$$

- Carpathian Basin:

$$
M=0.53 \cdot I_{0}+0.96 \quad \text { (Kárnik 1968). }
$$

Number of earthquakes used: 30. Range of the epicentral intensities: V-IX.

- Háromszék-Vrancea region:

$$
M=0.56 \cdot I_{0}+2.18 \quad \text { (Radu 1974). }
$$

Plotting these relationships with our results in Fig. 16 it can be concluded that the new magnitude-intensity Eq. (10) predicts greater magnitude than the equation of Csomor-Kiss (1959) but smaller than the relation of Kárnik (1968) at a given epicentral intensity in the Carpathian Basin. For the Háromszék-Vrancea region the new relationship (12) predicts smaller magnitude comparing to the one of Radu (1974). 


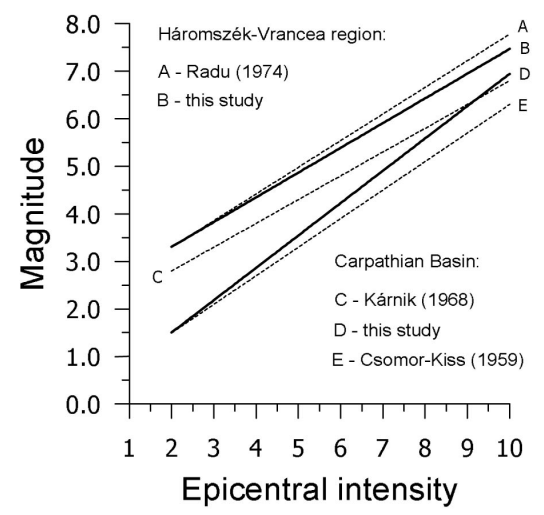

Fig. 16. Comparison of magnitude - epicentral intensity relationships

\section{Appendix I}

Location names in different languages

\begin{tabular}{|c|c|c|c|c|c|c|c|}
\hline Hungarian & Austrian & Croat & Moravian & Rumanian & Serb & Slovak & Ukrainian \\
\hline Belgrád & & & & & \multicolumn{3}{|c|}{ Beograd } \\
\hline Bécs & Wien & & & & & & \\
\hline Bukarest & & & & Bucureşti & & & \\
\hline Csernovic & & & & & & & Csernovtsi \\
\hline Fiume & & Rijeka & & & & & \\
\hline Grác & Graz & & & & & & \\
\hline Kassa & & & & & & Košice & \\
\hline Kolozsvár & & & & Cluj-Napoca & & & \\
\hline Lemberg & & & & & & & Lviv \\
\hline Nagyszeben & & & & Sibiu & & & \\
\hline Ógyalla & & & & & & Hurbanovo & \\
\hline Temesvár & & & & Timişoara & & & \\
\hline Ungvár & & & & & & & Uzhchorod \\
\hline Zágráb & & Zagreb & & & & & \\
\hline Zsolna & & & & & & Zilina & \\
\hline
\end{tabular}




\section{References}

Bielz E A 1862-1863: Beitrag zur Geschichte merkwürdiger Naturbegebenheiten in Siebenbürgen. Verhandlungen und Mitteilungen des Siebenbürgischen Vereines für Naturwissenschaften zu Hermannstadt

Bisztricsány E, Csomor D 1981: Acta Geod. Geoph. Hung., 16, 423-434.

Cecic I, Musson M R, Stucchi M 1996: Annali di Geofisica, 39, 1013-1027.

Csomor D, Kiss Z 1959: Geofizikai Közlemények, 7, 169-180 (in Hungarian).

Csomor D, Kiss Z 1962: Geofizikai Közlemények, 11, 51-75 (in Hungarian).

Ferrari G ed. 1997: Proceedings of the Workshop: Historical Seismic Instruments and Documents: a Heritage of Great Scientific and Cultural Value. Luxembourg.

Fuchs C W C 1886: Sitzungsb. der k. Akad. der Wissensch., 92, 215-625.

Grossinger J 1783: Dissertation de Terrae Motibus Regni Hungariae. Jaurini (Győr)

Hantken M 1882: Magyar Királyi Földtani Intézet Évkönyve, 4, 43-121 (in Hungarian).

Hoff K E A 1840-1841: Chronik der Erdbeben und Vulcan-Ausbrüche. Gotha

Horváth F 1993: Tectonophysics, 226, 333-357.

Hunfalvy J 1859: Királyi Magyar Természettudományi Társulat Évkönyvei (in Hungarian), $4,182-220$.

Jeitteles L H 1859: Sitzungsb. der k. Akad. der Wissensch., 35, 511-591.

Jeitteles L H 1860a: A k. m. Természettudományi Társaság Közlönye (in Hungarian), $171-181$.

Jeitteles L H 1860b: Zeitschrift der Deutschen Geologischen Gesellschaft, 12, 287-349.

Kárnik V 1968: Seismicity of the European Area I. Praha

Kitaibel P, Tomtsányi A 1814: Dissertatio de terrae motu in genere ac in specie Mórensi anno 1810 die 14. Januario orto. Budae

Koch A 1881: The Central-Transylvanian earthquakes of October 3, 1880 (in Hungarian). Orvos-Természettudományi Értesítő, Kolozsvár

Kornhuber G A 1858: Verhandlungen des Vereins für Naturkunde zu Pressburg, 3, 23-54.

Kövesligethy R 1906: Mathematikai és Természettudományi Értesítö (in Hungarian), 24, 349-368.

Lenkey L 1999: Geothermics of the Pannonian Basin and its bearing on the tectonics of basin evolution. Vrije Universiteit, Amsterdam

Mallet R 1858: Catalogue of all recorded earth quaques from 1606 b. Chr. To A. D. 1842. London

Oncescu M C, Burlacu V, Anghel M, Smalberger V 1984: Tectonophysics, 106, 305-319.

Perrey A 1846: Mémoire sur les tremblements de terre dans le bassin du Danube. Lyon

Radu C 1974: Contribution a l'étude de la seismiciti de la Roumanie et comparaison avec la séismicité du bassin méditerranéen et en particulier avec la séismicité du Sud-Est de la France. Thése Dr. Sc. Université Louis Pasteur, Strasbourg

Réthly A 1952: Earthquakes of the Carpathian Basins (455-1918) (in Hungarian). Budapest

Schuster M 1881: Verhandlungen und Mittheillungen des Siebenbürgischen Vereins für Naturwissenschaften, 31, 107-243.

Smidt J F 1858: Mittheilungen der k. k. geogr. Gesellschaft, 2, 131-202.

Spakman W 1990: Terra Nova, 2, 542-553.

Stucchi M, Albini P 1991: In: Proc. Mexico-EC Workshop "Seismology and Earthquake Engineering", 47-70.

Suess F E 1897: Jahr. d. k. k. geol. Reichsanstalt, 46, 411-890.

Szeidovitz Gy 1994: Acta Geod. Geoph. Hung., 29, 197-208. 
Torbar J 1882: Study of the Zagreb earthquake of November 9, 1880. Zagreb (in Croat).

Tóth L, Mónus P, Zsíros T 1996: Hungarian Earthquake Bulletin 1995. Georisk- MTA GGKI, Budapest

Tóth L, Mónus P, Zsíros T 1997: Hungarian Earthquake Bulletin 1996. Georisk, Budapest Tóth L, Mónus P, Zsíros T 1998: Hungarian Earthquake Bulletin 1997. Georisk, Budapest Tóth L, Mónus P, Zsíros T 1999: Hungarian Earthquake Bulletin 1998. Georisk, Budapest Wahner F 1883: Sitzb. d. mathem.-naturw., 88, 15-344.

Willmore P L ed. 1979: Manual of seismological observatory practice. World Data Center A for Solid Earth Geophysics, Report SE-20, Boulder

Zsíros T 1996: Macroseismic focal depth and intensity attenuation in the Carpathian region, Acta Geod. Geoph. Hung., 31, 115-125.

Zsíros T 2000: Seismicity and seismic hazard of the Carpathian Basin: Hungarian earthquake catalogue (456/-1995) (in Hungarian), MTA FKK GGKI, Budapest

Zsíros T, Mónus P, Tóth L 1988: Hungarian Earthquake Catalogue (456-1996). Seismological Observatory, Budapest 